\title{
PENGARUH PEMBERIAN JUS JAMBU BIJI MERAH TERHADAP JUMLAH LEUKOSIT PADA AKTIFITAS FISIK MAKSIMAL
}

\author{
Oleh \\ Fajar Apollo Sinaga ${ }^{1}$, Marsal Risfandi ${ }^{2,}$ Mandike Ginting ${ }^{3}$, Khairani Fitri ${ }^{4}$ \\ ${ }^{1}$ Fakultas Ilmu Keolahragaan Universitas Negeri Medan \\ ${ }^{2}$ Fakultas Ilmu Keolahragaan Universitas Negeri Medan \\ ${ }^{3}$ Fakultas Farmasi Institut Kesehatan Helvetia \\ ${ }^{4}$ Fakultas Farmasi Institut Kesehatan Helvetia \\ Email: sinaga_fajar@yahoo.com
}

\begin{abstract}
Abstrak
Aktifitas fisik dapat menyebabkan peningkatan produksi radikal bebas yang menyebabkan terjadi stress oksidatif akibat jumlah radikal bebas melebihi jumlah antioksidan tubuh. Stres oksidatif dapat menyebabkan peningkatan jumlah leukosit. Jumlah leukosit perifer dapat menjadi sumber informasi untuk diagnosa dan prognosa serta gambaran kerusakan organ dan pemulihan setelah olahraga. Radikal bebas dapat dicegah atau dikurangi dengan pemberian antioksidan. Telah diketahui buah jambu biji merah mengandung antioksidan. Tujuan penelitian adalah untuk mengetahui pengaruh pemberian jus buah jambu biji merah terhadap jumlah leukosit pada aktifitas fisik maksimal. Jenis penelitian yang dilakukan adalah penelitian eksperimental dengan rancangan penelitian randomized control group pretest-postest design. Sampel penelitian adalah mahasiswa Ilmu Keolahragaan sebanyak 30 orang yang memenuhi kriteria. Selanjutnya sampel dibagi atas 3 kelompok $(P 1=10, P 2=10$, dan $P 3=10)$. Selama menjalani program latihan kelompok P1 diberi Jus Buah Jambu Biji Merah 1x1 hari, P2 diberi 3x1 hari, dan P3 sebagai kontrol. Pengukuran jumlah leukosit dilakukan sebelum latihan dan setelah melakukan aktifitas fisik maksimal. Berdasarkan analisis statistik, terdapat perbedaan jumlah leukosit dibandingkan dengan kelompok kontrol setelah melakukan aktifitas fisik maksimal $(p<0,05)$. Hasil penelitian menyimpulkan pemberian jus buah jambu biji merah selama latihan dapat menngurangi peningkatan jumlah leukosit yang disebabkan oleh aktivitas fisik maksimal.
\end{abstract}

Kata kunci: Jus jambu biji merah, Aktifitas fisik maksimal, Jumlah leukosit

\section{A. PENDAHULUAN}

Sel secara rutin menghasilkan radikal bebas dan kelompok oksigen reaktif (reactive oxygen species/ROS) yang merupakan bagian dari proses metabolisme (Daniel et al, 2010; Urso, 2003). Radikal bebas adalah setiap molekul yang mengandung satu elektron atau lebih yang tidak berpasangan (Clarkson dan Thomson, 2000, Silalahi, 2006). Radikal bebas yang termasuk kelompok oksigen reaktif (ROS) diantaranya adalah radikal superoksid, radikal hidroksil, radikal hidroksil peroksida dan oksigen tunggal (Daniel et al, 2010). Pada saat produksi radikal bebas melebihi antioksidan pertahanan seluler maka dapat terjadi stres oksidatif, dimana salah satu faktor 
penyebabnya adalah akibat aktifitas fisik (Daniel et al, 2010; Urso, 2003) yang dapat mengakibatkan kerusakan pada sel-sel (Dekany et al, 2008).

Radikal bebas yang terbentuk di dalam tubuh akan dinetralkan oleh elaborasi sistem pertahanan antara antioksidan enzim-enzim seperti katalase (CAT), superoksid dismutase (SOD), glutation peroxidase (GPx) dan sejumlah anti oksidan non enzim termasuk diantaranya vitamin $\mathrm{A}, \mathrm{E}$ dan $\mathrm{C}$, glutatione, ubiquinone dan flavonoid (Urso, 2003).

Pada saat produksi radikal bebas melebihi antioksidan pertahanan seluler maka dapat terjadi stres oksidatif (Daniel et al, 2010). Beberapa hasil studi melaporkan bahwa aktifitas fisik aerobik akut berkontribusi terhadap stress oksidatif khususnya ketika latihan dengan intensitas tinggi. Dua mekanisme yang menyebabkan stress oksidatif pada latihan aerobik dengan intensitas tinggi adalah meningkatnya pro-okssidan melalui efek peningkatan konsumsi oksigen yang meningkat 10 sampai 15 kali dibandingkan pada saat istirahat dan antioksidan yang relatif/tidak mencukupi/dibandingkan prooksidan (Alessio et al, 2000). Sementara itu menurut Ji (1999), selama aktifitas fisik maksimal konsumsi oksigen seluruh tubuh meningkat sampai 20 kali, sedangkan konsumsi oksigen pada serabut otot diperkirakan meningkat sampai 100 kali lipat.

Pada kondisi stres oksidatif, radikal bebas akan menyebabkan terjadinya peroksidasi lipid (Evans, 2000), kerusakan pada jaringan otot (Vina, et al., 2000), perubahan aktifitas antioksidan enzim (Urso, 2003), meningkatkan jumlah leukosit lebih dari $10.000 \mathrm{sel} / \mu \mathrm{L}$ (Gokhan et al., 1992 yang akhirnya dapat mempengaruhi performance atlet. Jumlah leukosit perifer dapat menjadi sumber informasi untuk diagnosa dan prognosa serta gambaran kerusakan organ dan pemulihan setelah olahraga (Sodique et al., 2000).

Hasil penelitian yang dilakukan oleh Patlar, 2010 yang meneliti tentang pengaruh aktifitas fisik akut dan latihan selama 4 minggu dengan intensitas submaksimal melaporkan terjadi peningkatan jumlah leukosit. Hasil penelitian ini sejalan penelitian yang melaporkan bahwa berlari pada treadmill selama 30 menit dengan intensitas $85 \%$ dari VO2max dan dengan intensitas 60\% VO2max selama 90 menit dapat meningkatkan jumlah leukosit (Valizadeh dkk, 2011).

Turunnya kadar antioksidan, meningkatnya jumlah leukosit dan terjadinya peroksidasi lipid akibat aktifitas fisik sejalan dengan pernyataan Colgan, 1986 yang 
mengemukakan bahwa bahwa atlet di bawah pelatihan berat dan kompetisi tidak mampu mempertahankan kadar antioksidan secara optimal pada jaringan. Sehubungan dengan itu, Gomez (2008) mengatakan kerusakan oksidatif akibat aktifitas fisik mungkin dapat dicegah dengan mengoptimalkan gizi, terutama dengan meningkatkan kandungan antioksidan makanan. Menurut Silalahi (2006) khasiat antioksidan akan lebih efektif bila mengkonsumsi sayur-sayuran atau buah-buahan yang kaya antioksidan dari berbagai jenis dari pada menggunakan antioksidan tunggal seperti vitamin E. Hal ini mungkin dikarenakan oleh adanya komponen lain dan interaksinya dalam sayur-sayuran dan buah-buahan yang berperan secara positif.

Salah satu alternatif bahan alam yang mempunyai kandungan antioksidan adalah buah jambu biji merah. Buah jambu biji merah diketahui mempunyai kandungan vitamin C lima kali lebih besar dibandingkan dengan buah jeruk (Kumar, 2012). Senyawa lain dalam buah jambu biji yang berfungsi sebagai antioksidan adalah karotenoid seperti beta-karoten, lycopene, beta-cryptoxanthip/dan polifenol (Nascimento et al, 2010; Oliveira et al, 2010; Ordonez-Santos/dan Vazquez-Riäscos, 2010). Sebagai antioksidan, $\beta$-karoten bekerja menangkap radikal bebas terutama radikal peroksil dan hidroksil dan $\beta$-karoten bekerja sinergis dengan vitamin $\mathrm{C}$ dan $\mathrm{E}$ (Silalahi,2006).

Keistimewaan buah jambu biji yang memiliki berbagai jenis antioksidan dan potensi aktivitas antioksidannya yang besar, membuat peneliti merasa tertarik dan perlu meneliti efek antioksidan buah jambu biji merah terhadap kadar hematologi pada aktifitas fisik maksimal.

\section{B. METODOLOGI PENELITIAN}

Jenis penelitian adalah penelitian eksperimental dengan rancangan pre-test posttest, control group design. Subjek penelitian sebanyak 30 orang dengan kriteria mempunyai tingkat $\mathrm{VO}_{2} \max$ yang baik, jenis kelamin laki-laki, umur 20-22 tahun, memiliki IMT yang baik, tidak perokok, tidak mengkonsumsi suplemen dan antioksidan 2 minggu sebelum dan selama penelitian, bersedia menjadi subjek penelitian. Lokasi penelitian dilakukan di Stadion Universitas Negeri Medan (UNIMED) dan Laboratorium Kesehatan Daerah Provinsi Sumatera Utara. 
Bahan dan alat penelitian diantaranya jambu biji merah, larutan EDTA $1 \%$ aquadest. hematology analizer, alat-alat gelas, spuit, blender. Variabel bebas adalah jus buah jambu biji merah (JBJBM) dan variabel terikat adalah jumlah leukosit.

\section{Pelaksanaan Penelitian}

Penelitian menggunakan 30 orang mahasiswa yang memenuhi kriteria. Semua atlet dilakukan pemeriksaan hematologi untuk pemeriksaan hematologi (pretest). Selanjutnya atlet dibagi atas 3 kelompok $(\mathrm{P} 1=10, \mathrm{P} 2=10$, dan $\mathrm{P} 3=10)$. Selama menjalani program latihan kelompok P1 diberi JBJBM 1x1 hari, P2 diberi JBJBM 3x1 hari, P3 sebagai kontrol. Kemudian semua atlet melakukan aktifitas fisik maksimal dengan melakukan bleep test. Selanjutnya kembali dilakukan pengukuran hematologi kembali Pelaksanaan Bleep test

2. Siapkan kaset beserta tapenya. Peserta tes disuruh melakukan pemanasan dan peregangan

3. Dihidupkan kaset dilakukan seluruh peserta melakukan lari multi tahap (bleep test) sampai peserta tidak mampu lagi mengikuti irama yang telah ditentukan.

\section{Pemeriksaan Hematologi}

Pemeriksaan haemoglobin dilakukan dengan menggunakan hematologi analizer. Prosedur pemeriksaan dengan mengikuti manual prosedur yang sudah ditetapkan.

Analisis statistik dengan menggunakan uji normalitas, homogenitas dan uji t dan uji anova.

\section{HASIL DAN PEMBAHASAN}

\section{Data Berat Badan (BB) dan Tinggi Badan (TB)}

Kegiatan penelitian ini telah memeriksa sampel sebanyak sebanyak 30 orang. Usia sampel berkisar antara 19-20 tahun. Data rerata Berat Badan dan Tinggi Badan dapat dilihat pada tabel 1 . 
Tabel 1. Nilai Rerata Berat Badan (BB) dan Tinggi Badan (TB) Sampel

\begin{tabular}{|c|c|c|c|c|}
\hline Variabel & Group & $\mathrm{N}$ & Mean & Sig \\
\hline \multirow{3}{*}{ Berat Badan } & P1 & 10 & 59.50 & \multirow{3}{*}{0,925} \\
\cline { 2 - 4 } & $\mathrm{P} 2$ & 10 & 59,65 & \\
\cline { 2 - 4 } & $\mathrm{P} 3$ & 10 & 59.70 & \\
\hline \multirow{3}{*}{ Tinggi Badan } & P1 & 10 & 1.66 & \multirow{2}{*}{0,155} \\
\cline { 2 - 4 } & $\mathrm{P} 2$ & 10 & 1,65 & \\
\cline { 2 - 4 } & $\mathrm{P} 3$ & 10 & 1.68 & \\
\hline
\end{tabular}

Dari tabel $1 \mathrm{di}$ atas setelah dianalisis menggunakan uji statistika independent samples t-test, Berat Badan dan Tinggi Badan kelompok kontrol dan eksperimen memberikan hasil tidak berbeda secara bermakna $(p>0,05)$. Tidak adanya perbedaan $\mathrm{BB}$ dan $\mathrm{TB}$ sampel dalam penelitian menggambarkan bahwa sampel memiliki kemampuan dan kekuatan fisik yang sama, sehingga dalam perlakuan penelitian diharapkan tidak terdapat perbedaan yang berarti yang dapat mempengaruhi hasil penelitian yang disebabkan oleh ketidaksamaan kemampuan dan kekuatan sampel.

\section{Data Jumlah Leukosit Sebelum dan Sesudah Pemberian Jus Buah Jambu Biji Merah Setelah Melakukan Aktifitas Fisik Maksimal}

Berdasarkan hasil penelitian yang dilakukan jumlah leukosit sebelum dan sesudah pemberian Jus Buah Jambu Biji Merah ditunjukkan pada tabel 2.

Tabel 2. Rata-rata jumlah leukosit sebelum dan sesudah pemberian jus buah jambu biji merah setelah melakukan aktifitas fisik maksimal

\begin{tabular}{lcccc}
\hline \multirow{2}{*}{\begin{tabular}{c} 
Jumlah Leukosit $\left(10^{9} / \mathrm{l}\right)$ \\
\cline { 2 - 4 }
\end{tabular}} & \multicolumn{3}{c}{ Kelompok } & Anova \\
\cline { 2 - 5 } & $\mathrm{P} 1$ & $\mathrm{P} 2$ & $\mathrm{P} 3$ & $\mathrm{p}$ \\
\hline Pretest & $06,80 \pm 0,65$ & $06,93 \pm 0,62$ & $06,87 \pm 0,77$ & 0,914 \\
\hline Postest & $10,05 \pm 0,62$ & $08,83 \pm 0,91$ & $13,21 \pm 0,59$ & $0,000^{*}$ \\
\hline t-dependent & $0,000^{*}$ & $0,000^{*}$ & $0,000^{*}$ & \\
\end{tabular}

Keterangan: * sangat signifikan $(\mathrm{p}<0,05)$

Dari hasil uji analisis data sebelum dan sesudah eksperimen diperoleh data adalah terdistribusi normal dan homogen baik kelompok kontrol maupun kelompok eksperimen. Hasil uji statistik dengan menggunakan uji t (Paired Samples Test) diperoleh hasil terdapat perbedaan jumlah leukosit baik kelompok P1 (Pemberian Jus 
Jambu Biji Merah 1x1 hari), P2 (Pemberian Jus Jambu Biji Merah 3x1 hari) maupun P3 (Kontrol) $(\mathrm{p}=0,000)$. Hasil uji statistik dengan menggunakan uji anova menujukkan bahwa pada kondisi awal (pretest) jumlah leukosit tidak terdapat perbedaan antara P1;P2 dan P3 dengan nilai p 0,914. Jumlah leukosit post test berbeda secara signifikan antara kelompok $\mathrm{P} 1 ; \mathrm{P} 2$ dan $\mathrm{P} 3$ dengan nilai $\mathrm{p}=0,000$ seperti ditunjukkan pada gambar 1

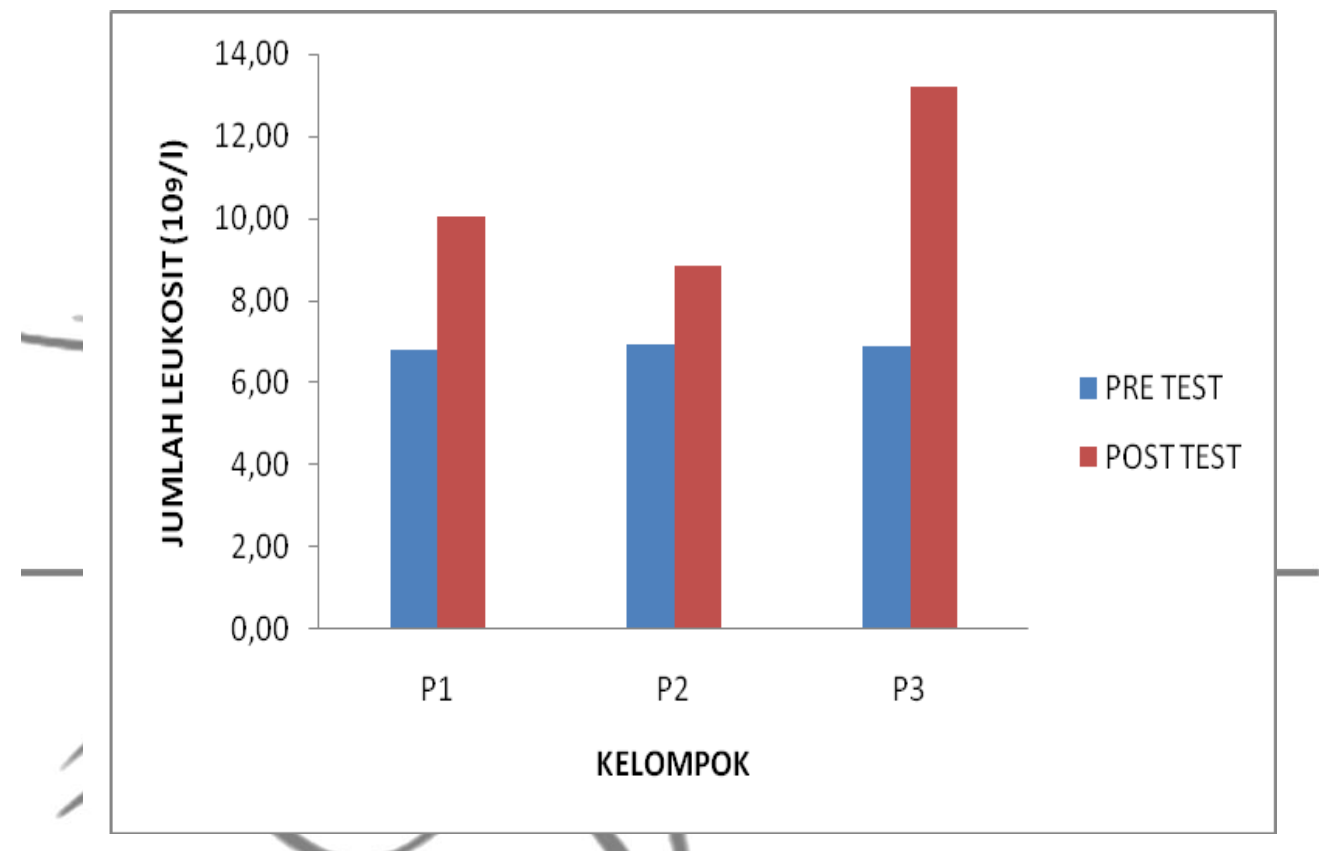

Gambar 1. Rerata jumlah leukosit antara kelumpok P1; P2 dan P3

Peningkatan jumlah leukosit setelah melakukan aktifitas fisik maksimal sesuai dengan pendapat peneliti yang menyatakan bahwa aktivitas fisik yang berat dan melelahkan, memicu jumlah radikal bebas melebihi kemampuan kapasitas sistem pertahanan antioksidan, dan ketidakseimbangan ini dapat menyebabkan stres oksidatif yang pada akhirnya dapat merangsang aktivitas sel lekosit sehingga memicu terjadinya peningkatan jumlah lekosit melebihi jumlah base line hitung lekosit (Nieman, 2000). Menurut Cooper jika radikal bebas yang terbentuk melebihi 5\% akibat aktifitas fisik berat, maka antioksidan di dalam tubuh tidak mampu untuk menetralkan produksi radikal bebas sehingga menimbulkan strees oksidatif yang akan merangsang sel leukosit (Cooper, 2000). Hal ini didukung hasil penelitian yang melaporkn stres oksidatif akibat aktifitas fisik dapat mengakibatkan terjadinya penurunan jumlah antioksidan (Thirumalai, 2011). Apabila aktivitas antioksidan terganggu, maka akan terjadi penimbunan superoksida dan hidrogen peroksida sehingga terbentuk reaksi 
berantai yang dapat menyebabkan cedera dan peradangan jaringan. Pada saat terjadi kerusakan jaringan atau cedera,yang pertama kali datang di tempat cedera atau peradangan ini adalah leukosit khususnya neutrofil. Leukosit akan bermigrasi dengan cepat dan berkumpul di jaringan yang mengalami cedera. Senyawa kimia yang dilepaskan dari jaringan yang meradang merupakan faktor penginduksi leukositosis. Faktor ini berdifusi dari jaringan yang meradang ke dalam darah dan dibawa ke sumsum tulang yang menyebabkan pelepasan leukosit terutama neutrofil (Guyton dan Hall, 2008).

Peningkatan jumlah leukosit setelah aktifitas dikarenakan banyaknya leukosit yang mengikut (masuk) ke dalam dinding pembuluh darah (endothelium) dengan cara diapenesis ke dalam sirkulasi dari penyimpanannya (cadangan) secara tiba-tiba (Sodique, 2000). Demarginasi dipengaruhi oleh hormon adrenalin yang menyebabkan menurunnya perlekatan leukosit pada endotelium/Hasil penelitian ini sejalan dengan penelitian yang dilaporkan bahwa pada aktifitas/singkat ( $<1$ jam), /hanya pengaruh katekolamin yang menyebabkan terjadinya peningkatan ratio sirkulasi ke non sirkulasi sel yang mengakibatkan peningkatan mobilisasi leukosit/dari sumsum tulang ke darah sehingga terjadi proses demarginasi dari dinding pembuluh darah secara diapenesis (Sodique, 2000., Risoy, 2003). Peningkatan jumlah sel darah putih pada kelompok kontrol sesuai dengan laporan penelitian yang dilakukan oleh Harahap (2008) dan Suzuki (2004) yang melaporkan adanya peningkatan jumlah leukosit setelah melakukan aktifitas fisik maksimal dan aktifitas fisik yang berat secara singkat yang berkisar antara 15 menit, maupun aktifitas fisik yang berat dan lama sampai 60 menit. Peningkatan jumlah leukosit juga terjadi pada latihan dengan intensitas sub maksimal (Patlar, 2010, Valizadeh dkk, 2011).

Pemberian jus buah jambu biji merah (JBJBM) pada penelitian ini dapat mengurangi peningkatan jumlah leukosit dibandingkan dengan kelompok kontrol pada saat melakukan aktifitas fisik maksimal. Berkurangnya peningkatan jumlah leukosit lebih besar pada kelompok P2 (JBJBM 3x1 hari) dibandingkan dengan P1 (JBJBM 1x1 hari). Hal ini tentu berkaitan dengan dosis pemberian, dimana semakin besar dosis yang diberikan, maka kadar antioksidan semakin tinggi untuk menetralkan radikal bebas yang terbentuk pada saat melakukan aktifitas fisik maksimal. Hasil penelitian ini didukung oleh penelitian yang dilakukan oleh Rahman, dkk yang melaporkan bahwa 
mengkonsumsi buah jambu biji merah dapat meningkatkan antioksidan tubuh (Ahmad dkk, 2006).

Buah jambu biji merah diketahui mempunyai kandungan vitamin $\mathrm{C}$ lima kali lebih besar dibandingkan dengan buah jeruk (Kumar, 2012). Senyawa lain dalam buah jambu biji yang berfungsi sebagai antioksidan adalah karotenoid seperti beta-karoten, lycopene, beta-cryptoxanthin dan polifenol (Nascimento et al, 2010; Oliveira et al, 2010; Ordonez-Santos dan Vazquez-Riascos, 2010). Sebagai antioksidan, $\beta$-karoten bekerja menangkap radikal bebas terutama radikal peroksil dan hidroksil dan $\beta$-karoten bekerja sinergis dengan vitamin C dan E (Silalahi, 2006). Likopen mampu menstimulasi kerja enzim antioksidan seperti SOD, GPX, dan katalase. Enzim SOD berfungsi untuk mencegah penimbunan superoksida, enzim katalase dan GPx mencegah penimbunan $\mathrm{H}_{2} \mathrm{O}_{2}$ dengan jalan menguraikan $\mathrm{H}_{2} \mathrm{O}_{2}$ menjadi $\mathrm{H}_{2} \mathrm{O}$ atau $\mathrm{H}_{2} \mathrm{O}+\mathrm{O}_{2}$. Dengan berkurangnya $\mathrm{H}_{2} \mathrm{O}_{2}$ berarti terbentuknya radikal hidroksil dapat dicegah, sehingga terjadinya lipid peroksidasi akan semakin berkufang dan peradangan atau kerusakan jaringan dapat dicegah (Winarsi, 2007).

\section{KESIMPULAN}

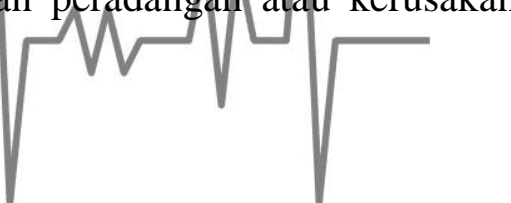

Dari hasil penelitian disimpulkan pemberian jus buah jambu biji merah pada atlet selama menjalani program latihan dapat mengurangi peningkatan jumlah leukosit pada saat melakukan aktifitas fisik maksimal.

Disarankan kepada atlet selama menjalani program latihan untuk meningkatkan status antioksidan tubuhnya dengan mengkonsumsi antioksidan alami untuk mencegah terjadinya stressoksidatif akibat aktifitas fisik terutama aktifitas fisik berat.

\section{DAFTAR PUSTAKA}

Colgan, M. (1986). Effects of multinutrient supplementation on athletic performance. In Katch, F.I. (Ed) Sport, Health, and Nutrition, Human Kinetics: pp21-50

Cooper, K.H. 2001. Sehat tanpa Obat: 4 Langkah Revolusi Antioksidan terjemahan dari Textbook of Antioxidant Revolution. Kaifa Bandung

Daniel, R.M., Stelian, S., Dragomir, C. (2010), The effect of acute physical exercise on the antioxidant status of the skeletal and cardiac muscle in the Wistar rat. Romanian Biotechnological Letters. Vol. 15, No. 3, Supplement, p 56-61.

Dekany,M., Nemeskeri, V., Gyore, I., Ekes, E., Gogl, A., Szots, G., Petrekanits, M., Taylor, A.W., Berkes,I., Pucsok, J., (2008). Physical performance and antioxidant effects Iin triathletes. Biology of Sport, Vol. 25. 101-114.

Evans, W. J. (2000), Vitamin E, vitamin C, and exercise. Am J Clin Nutr, 72, 647S-52S. 
Gomez-Cabrera MC, Domenech E \& Vin a J (2008) Moderate exercise is an antioxidant: upregulation of antioxidant genes by training. Free Radic Biol Med. 44, 126-131

Guyton, A.C. and Hall, J.E. 2008. Buku Ajar Fisiologi Kedokteran (Textbook of Medical Physiology). Edisi 11. Alih Bahasa: Irawati, dkk. EGC. Jakarta.

Kumar,A. (2012). Importance for Life 'Psidium guava'. International Journal of Research in Pharmaceutical and Biomedical Sciences. Vol. 3 (1). 137-143

Nascimento RJ, Araújo CR, Melo EA (2010). Antioxidant from agriindustrial wastes of the guava fruits (Psidium guajava L) Alim Nutr. 21: 209-16Ostojic, S.M., Stojanovic, M.D., Djordjevic, B., Jourkesh, M., Vasiljevic, N. (2008). The Effect of a 4-Week Coffeberry Suplementation on Antioxidant Status, Endurance, and Anaerobic Performance in College Athletes. Research in Sports Medicine, 16: 281-294

Nieman, C. D. Exercise Effects On Systemic Immunity. Immunology And Cell Biology, 2000. 78, 496-501

Oliveira D S, Lobato AL, Ribeiro SM, Santana AM, Chaves JB (2010). Carotenoids and Vitamin C during Handling and Distribution of Guava (Psidium guajava L.), Mango (Mangifera indica L.), and Papaya (Carica papaya L.) at Commercial Restaurants. J. Agric Food Chem. 58:6166-6172

Ordonez-Santos LE, Vazquez-Riascos A (2010). Effectof processing and storage time on the vitamin $\mathrm{C}$ and lycopene ophtents of nectar of pink guava (Psidium guajava L). Arch Latinoam Nutr.60: 280-284.

Patlar.S. (2010). Effects of acute and 4week submaximal exercise on leukocyte and leukocyte subgroups. Isokinetics and Exercise Science 18 hal 145-148

Rahmat, A., Abu Bakar, M.F and Hambali, Z. (2006). The Effects Of Guava (Psidium Guajava) Consumption On Total Antioxidant And Lipid Profile In Normal Male Youth. African journal of food agriculture nutrition and development. Vol 6 no 2.

Silalahi, J. (2006). Makanan Fungsional. Penerbit Kanisius Yokyakarta. Halaman 38-56

Sodique, N.O., Enyikwola, O., and Ekanem, A.U. 2000. Exercise-induced Leucocytosis in some Healthy Adult Nigerians. African Journal of Biomedical Research.

Thirumalai, T., Viviyan T. S., Elumalai,E.K., David, E. (2011). Intense and exhaustive exercise induce oxidative stress in skeletal muscle, Asian Pacific Journal of Tropical Disease 63-66

Urso, M.L., Clarkson, P.M. (2003), Oxidative stress, exercise, and antioxidant supplementation. Toxicology 189(1-2):41-54

Valizadeh, A., Hossini, M.K., dan Heris,M.S. (2011). Immune response to changes in training intensity and duration in male athletes. Annals of Biological Research, 2011, 2 (6):662-667

Vina J, Gomez-Cabrera MC, Lloret A, Marquez R, Minana JB, Pallardo FV (2000). Free radicals in exhaustive physical exercise: mechanism of production and protection by antioxidants. IUBMB Life, 50: 271-7.

Winarsi,H.2007. Antioksidan Alami dan Radikal Bebas. Penerbit Kanisius. Yogyakarta 